\title{
The Nationalisation of the Domestic Sphere
}

\author{
Post-print
}

Original published in:

Nations and Nationalism (2016)

http://onlinelibrary.wiley.com/doi/10.1111/nana.12290/full DOI: $10.1111 /$ nana. 12290

\author{
Eric Storm \\ Institute for History \\ Leiden University
}




\begin{abstract}
Banal forms of nationalism permeate our everyday life. However, it is not very clear when all kinds of banal objects and practices became nationalised. In this article, I focus on the domestic sphere by analysing how around 1900 a small group of activists began to propagate the nationalisation of domestic architecture, decorative arts and even gardening. Domestic practices such as cooking, cleaning and consuming were nationalised at about the same time, at least in Western Europe. Although in the beginning the nationalisation of the domestic sphere was perceived as something new, within a few decades the existence of national cuisines and architectural styles was taken for granted. As a consequence, it becomes clear that the nationalisation of the domestic sphere constituted a new and very successful phase in the nation-building process, which now also began to affect quotidian practices and objects in the private realm.
\end{abstract}

\title{
Keywords
}

Everyday Nationalism - Domestic Architecture - Food Studies - Domestic Sphere - Gender - Decorative Arts

Word count: 9,998 words

\section{Biographical note}

ERIC STORM lectures modern European History at Leiden University, the Netherlands. His research interests include Spanish history and the construction of national and regional identities in Western Europe. His main publications are: La perspectiva del progreso, Pensamiento político en la España del cambio de siglo (Madrid: Biblioteca Nueva 2001), The Culture of Regionalism: Art, Architecture and International Exhibitions in France, Germany and Spain, 1890-1939 (Manchester: Manchester University Press 2010), The Discovery of El Greco: The Nationalization of Art Versus the Rise of Modern Art (Eastborne: Sussex Academic Press 2016) and edited (with Joost Augusteijn) Region and State in NineteenthCentury Europe: Nation-Building, Regional Identities and Separatism (Basingstoke: Palgrave 2012).

\section{Acknowledgements}

This article is the product of a larger research project 'La nación desde la raíz. Nacionalismo español y sociedad civil en el siglo XX' funded by the Spanish Ministry of Economy and Competitiveness (HAR2012-37963-C02-01). 


\section{The Nationalisation of the Domestic Sphere}

Nowadays, people routinely divide the world into nation-states and identify with their own. The identification with 'our' soldiers, sportsmen and singers is taken for granted as a natural phenomenon as is the division between foreign and domestic news. When we speak about 'the government', 'the economy' or 'the countryside', we generally understand that we refer to the government, economy or countryside of our own country. We even associate different types of buildings, design, furniture, cuisine and gardens, but also cars, fashion, landscapes and popular music with particular nations. In fact, the nation-state has become internalised as the 'natural' unit in which we divide the world.

This is all the more remarkable considering that nation-states only came into existence some two hundred years ago and that most current nation-states were created after the Second World War. Even in Europe, most people lived in empires until the end of the First World War. It is obvious that nationalism did not enter everyday discourse overnight or that suddenly all sorts of goods became identified with specific nations. We already know quite well when nationalism began to affect high culture and when the nation-building process began to target the masses. However, it is much less clear when all kinds of banal objects and practices, for example those we employ on a daily basis at home, became nationalised. Therefore, I will examine the origins of the nationalisation of the domestic sphere in Western Europe.

Social scientists have already paid considerable attention to the nationalisation of our everyday life. Particularly influential were Michael Billig (1995), who uncovered how banal forms of nationalism are omnipresent in the media, in politics and academic discourse, and Tim Edensor (2002), who examined the quotidian reproduction of national identities in a multitude of spaces, objects and practices. Both have convincingly shown how nationalism permeates our everyday life and often is not even noticed anymore as such. It is a kind of dormant force that in times of conflict, rising tensions or international sporting events can easily come to the surface and even become 'hot' again (See also Hutchinson 2006; Jones and Merriman 2009; Skey 2009). Their ground-breaking studies have been a source of inspiration for hundreds of scholars across the globe. However, most of the investigations that were conducted in their wake focus on current topics or very recent developments.

Historians, in turn, have traditionally focused on national movements and the conscious nation-building activities of domestic elites. This way it has become clear that nationalism entered the lives of the Europeans in successive waves, deepening its impact over time. First the French Revolution and the Napoleonic Wars introduced the idea of the sovereignty of the nation and the equality of all citizens into political discourse (Bell 2003; Broers 2015). During the Romantic Era nationalism also invaded the cultural domain. National cultures were created by standardizing the national language and documenting the nation's traditional tales and stories, by formulating the canon of its artistic and cultural highlights and by preserving its cultural heritage in national museums, libraries and archives. Historians and archaeologists dug up documents and artefacts in order to provide their nation with a glorious and heroic national past, while artists and writers depicted its most eminent episodes in their work (Leerssen 2016; Berger and Conrad 2015; Díaz-Andreu 2007). The nation-building process entered a new phase with the extension of the suffrage and the rise of mass-politics during the second half of the nineteenth century. Nationalism now entered the streets to mobilise the masses, particularly on special occasions, such as national holidays, large scale commemorations or the burial of a national hero. The urban landscape, moreover, became speckled with nationalist statues and monuments (Thiesse 1999; Baycroft and Hewitson 2006; Cabo and Molina 2009; Leerssen and Rigney 2014). 
Over the past few years, historians have also begun to pay attention to more mundane forms of nationalism and its impact on daily life. Thus, local studies have shown how from the late nineteenth century onwards nationalism began to penetrate daily life in small towns (Stauter-Halstead 2001; King 2002; Waddy 2010). Authors such as Hagen (2006), Zuelow (2009) and Young (2012) made clear how the growing importance of tourism in about the same period stimulated the active identification of characteristic towns, typical dresses, customs and landscapes with the nation, while inducing, for instance, Ireland to become more Irish. Other investigators have focused on the growing role of nationalism in sports (Tomlinson and Young 2006; Quiroga 2013), popular culture (Young 2016) or marketing (Harp 2001).

Nonetheless, because of the dominant case study approach, this sill results in a very fragmented picture. The same is true for investigations dealing with the nationalisation of the domestic sphere. There are already a number of interesting investigations on certain aspects within one national context. However, the field is still very much divided between disciplines and subdisciplines, such as the history of architecture, decorative arts and gardening and gender, food and consumption studies. Moreover, until very recently, scholars within these disciplines concentrated primarily on topics related to modernisation and modernity, like the rise of the avant-garde, the growing role of women in the public sphere, the progress of hygienic ideas and new patterns of consumption and, as a consequence, almost ignored 'backward' movements such as nationalism and regionalism and their impact on the domestic sphere.

Based on an earlier research project, a number of recent studies and some additional investigations, this article will provide a more encompassing analysis of the nationalisation of the domestic sphere in Western Europe. The first part will focus on domestic architecture and interior decoration, while the second half will discuss the nationalisation of domestic practices such as cooking, consuming and cleaning. Since it is almost impossible to approach this through the perspective of the individual - for instance by doing interviews or surveys - these themes will be investigated primarily by way of articles in magazines, treatises, cookbooks and speeches. Most examples will be taken from France, Spain and Germany, while references will be made to other parts of Western Europe. This way I will show that this process began towards the end of the nineteenth century and became more manifest during the first decades of the twentieth century and that it was initiated by nationalist activists who appropriated all kinds of unreflected local or social habits for their nationalist project. This way, new national traditions were consciously constructed or even invented. In the end, this would prove to be a great success and many of these traditions are now totally taken for granted.

\section{Nationalising domestic space}

Nationalism had a large impact on architecture during the first half of the nineteenth century. However, this primarily affected monumental public buildings. The main question was to determine what past styles and architectural highlights from the recently defined national canon had to inspire newly constructed state buildings and commemorative monuments? This was often hotly debated and particularly the nationalist appropriation of the gothic style in various parts of Europe was striking (Bergdoll 2000: 139-71). Domestic architecture on the other hand largely followed rather eclectic international trends in which neo-classical or Beaux-Arts influences were dominant. Only towards the end of the century a new fascination for local vernacular examples became manifest. This new architectural vogue has been largely ignored in later historical overviews since - unlike the avant-garde - it did not produce resounding manifestos, nor present itself as a coherent movement. As a result, it is known 
with many different names, such as traditionalism or Heimat architecture in German-speaking areas, regionalism in France, Spain and Portugal, national-Romanticism in Scandinavia, or simply national style in many parts of East-Central Europe, while in Great Britain it is known as Queen Anne style or classified as part of the Arts and Crafts movement. Elsewhere, labels such as Pueblo or Prairie Style or adjectives such as Neocolonial or neo-indigenista are in use. This terminological confusion, nonetheless, conceals a surprisingly coherent architectural trend (Storm 2010: 74. See also Loyer and Toulier, 2001; Vigato 1994; Lampugnani and Schneider 1992; Navascués Palacio 1985; Lane 2000).

In 1904, Hermann Muthesius argued that this new tendency had originated in GreatBritain. In his voluminous study of English domestic architecture, which in the first decades of the twentieth century would play a fundamental role in propagating a new domestic architecture inspired by vernacular traditions in Central Europe, he asserted that England had been the first country where a rapidly growing number of upper-middle class dwellings were designed by professional architects. Many of them looked for inspiration in local artisanal building traditions and he pointed particularly to the second generation of Arts and Crafts architects, such as Charles Voysey, Mackey Hugh Baillie Scott and Charles Rennie Mackintosh as the main precursors of this neo-vernacular trend (1904: I, 100-12).

Scholars nowadays generally acknowledge the pioneering role of the British Arts and Crafts movement, but also point to wider developments. Thus, Amy Ogata emphasises the importance of a similar trend in city planning, where theorists like Camilo Sitte, Charles Buls and Joseph Stübben propagated a more preservationist attitude to ancient buildings and streetplans, while showing a preference for picturesque and organic ensembles instead of rational schemes with straight and uniform streets (2001: 59-80). Catherine Bertho-Lavenir equally links neo-vernacular architecture to a broader trend, which was also visible in the growing interest in the cultural heritage of the countryside and a new appreciation of vernacular traditions; all over Europe, new folkloric, ethnographic and hiking associations sprang up. At the same time, the popular culture of rural areas increasingly received attention at world fairs, first in quite modest shows of traditional dresses, artisanal products and dioramas, and from the international exposition in Vienna in 1873 onwards also in ethnographic villages. This new trend was institutionalised in 1891 with the opening of Skansen, the first open-air museum in Stockholm, which in turn was rapidly imitated elsewhere (2001). Vernacular traditions now also began to inspire the architecture of national pavilions at world fairs, where Scandinavian countries again played a pioneering role (Wörner 1999: 28-49). However, it is also clear that a younger, more activist generation that was preoccupied with the rise of masssociety took the lead (Storm 2010: 1-21; Storm 2012).

The outward appearance of the houses built in this new architectural trend diverged enormously, but this was a logical outcome of the quite unified and coherent ideas behind it. Architects should employ artisanal techniques and natural materials - such as timber, brick, stone, slate and straw - that were locally available to construct houses that fit well into the natural environment and respected existing vernacular traditions. The orientation of the dwelling was carefully chosen in order to provide the inhabitants with fresh air and daylight, while protecting them against the wind, rain and snow. Porches, terraces, conservatories, bowwindows and balconies were placed strategically in order to create beautiful vistas and provide easy access to the garden. The diverse materials and their natural colours, together with the different volumes and large protruding roofs created a picturesque ensemble that was both comfortable to live in and agreeable to the eye. Since climatic and natural conditions differed greatly across Europe, as did available building materials, artisanal techniques and traditional building types, the result varied enormously. Nevertheless, the outcome was not arbitrary; each house was to be recognisable as belonging to a specific area (Storm 2010: 73195). 
Several contemporary commentators explained that these new constructions had to reflect the local Volksgeist and thus reconnect the population to the soil and its native traditions. A house had to be adapted to the unique popular spirit of the area, which had been forged over the ages in the continuous interaction between the population and its natural environment. However, an architect should not slavishly copy existing forms, but employ local materials and traditions in order to design a modern building that was perfectly adjusted to both the needs of the client and the particularities of the site. Characteristic for this new view on vernacular traditions as the principal source of inspiration for new domestic constructions was an article published in 1909 by the French architect Louis Sézille in which he praised the artists and artisans of the French Basque Country for having created their own characteristic 'Basque style' by adapting themselves in the course of centuries to the local geographical and climatological circumstances:

And this way the artists, perfecting ceaselessly their local methods, have arrived at the mastery that surprises us: this is a precious lesson, and to equal them we thus have to imitate them in their way of working and of studying. (1909: 153-54)

The German critic Friedrich Seesselberg formulated the task of the architecture in a similar way, distinguishing clearly between vernacular constructions of the past and the neovernacular architecture of the present:

The farmers, the inhabitants of the towns and the artisans were not aware of the particular beauty of their construction methods; neither did they ask themselves why their thatched roofs, their half-timbering and their gables looked as if they were born directly from the landscape (1910: 88).

However, in modern times, because one was aware that elsewhere and in different periods other architectural styles existed, it was impossible to continue to construct in such an almost instinctual way:

The habitual art of the past is being substituted everywhere by outright 'initiative art'. This way, what people once did without education and all on their own - the correspondence with nature - should now be taught anew. One should now tell the people: look, you should do it this way in order to fit in with the landscape (Seesselberg 1910: 94).

Exactly this adaptation of the 'initiative art' to the environment and the local traditions is the task of the architect and required empathy and creativity. ${ }^{1}$

During the first decade of the twentieth century this neo-vernacular architecture became fashionable all over Europe, particularly for villas and cottages in new suburbs and garden-cities and for country houses and second homes at the beach, in the mountains or in the countryside. This meant that many new houses now were constructed in a neo-vernacular style and thus became connected to the soil and the local ancestral traditions and were recognisable as being typical for the area. What happened in fact was that by emphasising the specific character of each area, architects tended to select those vernacular traditions, building materials and artisanal techniques that could not be found elsewhere. To reflect the 'authentic' character of a region, new constructions adapted the most exceptional and striking features of some old local buildings in order to avoid that the end result resembled neo-vernacular constructions from elsewhere. This 'invention of tradition' meant that people slowly learned to distinguish regional and/or national architectural styles and that many new houses became 
more 'typical' and thus also more clearly linked to a nationally and regionally defined space. However, regional architectural styles, such as Breton or Normand, were seen as an integral part of the nation. At the same time, the nation was presented increasingly as a unity in diversity. $^{2}$

Already halfway through the nineteenth century Viollet-le-Duc had begun to restore national monuments and to make them more distinctive than they had been. Thus, in his restorations of the citadel of Carcassonne and the Notre-Dame in Paris he made them appear more medieval and gothic by removing all later additions and adding parts that according to him were missing (Bergdoll 2000: 165-7 and 225-32). Later this recipe was also applied to vernacular constructions and entire neighbourhoods. Thus, the Barrio de Santa Cruz, which was a miserable quarter of the medieval inner city of Seville, was converted into the Sevillian neighbourhood par excellence. Between 1912 and 1920 the streets were provided with new cobblestones, street signs and lampposts, while cosy squares and gardens were created, all in a typical 'Andalusian' style. The new houses that were constructed were even more characteristic than the existing ones, thus creating an extremely picturesque historical pastiche (Menéndez Robles 2007: 178-203. Storm 2013: 535-6). This also happened in Barcelona from the 1920s onwards, as the downtrodden old city centre was converted into a unique 'Barri Gòtic' (Cócolo Gant 2013).

The same process can be detected in suburbs, the countryside and tourist areas. Thus, the Andalusian countryside became dotted with new variants of whitewashed buildings in a regionalist style (Villar Movellán 1979: 312-30 and 383-400), in the southwest of France the traditional farm houses from the Labourd area were copied in the rest of the Basque Country and became a source for inspiration for neo-Basque buildings of all types, such as villas, cottages, hotels and apartment-buildings (Lasserre 1986: 69). In Normandy the colourful old manor houses with their characteristic half-timbered facades played a similar role (Sézille 1908, Maumené 1913). Particularly the Atlantic coast of France and Spain became crowded with neo-vernacular villas, hotels and restaurants. In the fashionable seaside resort of Deauville even the market and a petrol station were built in a neo-Norman style (Tournoux 1999). The same, however, also happened in the mountainous areas of Switzerland, Austria, Bavaria and Eastern Europe (Loyer and Toulier 2001). In Poland, the local variant of the neovernacular trend became known as the Zakopane style, after the ski resort at the foot of the Tatra Mountains from which it originated (Crowley 2001). Even cities like Hamburg and Amsterdam began to actively promote the use of vernacular traditions and local brick for the construction of entire new neighbourhoods (Jenkins 2003: 261-294; Stieber 1998).

Browsing through specialised magazines such as The Studio, Dekorative Kunst, Der Baumeister, Art Décoratif, La Vie à la Campagne, La Construcción Moderna and Cortijos y Rascacielos one can infer that between the late 1890s and the 1920s probably the majority of the new villas and cottages that were discussed in their pages could be categorised as neovernacular. From the illustrations and the accompanying text it becomes obvious that this style not only was applied to the exterior, but also architects often designed the interior and the furnishing in order to create an encompassing Gesamtkunstwerk that reconnected the inhabitant with the soil of the patria and its vernacular traditions. Thus, most country houses had a large hall with a massive fireplace. Family life was encouraged by cosy nooks where everyone could gather. In the summer, large doors provided easy access to the terrace and the garden. The gentlemen's room often had a separate entrance to avoid visitors passing through the living rooms. The kitchen was located close to the dining room and servants received well-lit rooms, which if possible were separated from the rest of the house (Heuss, 1910; Popp 1913: 8-9). A Spanish illustrated magazine even presented traditional rural kitchens, where the entire family gathered around the fireplace, as an inspiring example for modern houses $(E l$ Mundo en Auto 1925). 
The views of these architects and critics on the decorative arts were strikingly similar to their architectonic ideals. Furniture should be made of natural materials and should not be copied from foreign styles, but be inspired by local artisanal traditions. In Germany, this led to initiatives to revive the craft industry by founding workshops where artists and artisans worked together following the example of William Morris. In 1907, a national association, the Deutsche Werkbund, was founded to promote the renovation of the arts and crafts throughout the German Empire (Campbell 1978; Maciuika 2005; see also Lane 2000; Ogata 2001; Thiesse 2012). As a consequence, the new villas and cottages were filled with solid and practical neo-vernacular tables, chairs and cupboards, which often were simply defined as 'German'. In France, it took somewhat more time for the 'minor arts' to become infected with the nationalist virus, but an exhibition of decorative art from Munich at the 1910 Parisian Salon d'Automne caused a stir. Critics who were in favour of neo-vernacular architecture now also began to plea for a reform of the curriculum of the arts and crafts schools and a reorientation on regional crafts and artisanal traditions (Croisilles 1909; Forthuny 1913; see also Silver 1989; Troy 1991). A vast exhibition of decorative arts, which was planned for 1916, would show the way. ${ }^{3}$ A Spanish review of the Parisian International Exposition of Modern Industrial and Decorative Arts, which finally took place in 1925, explained that this nationalist reorientation had been a success. The author argued that the 'Art Nouveau nightmares' had been overcome and that France had thrown off 'the tiresome ballast of twenty years of foreign influences' and 'turned its eyes towards its glorious traditions' in order to re-nationalise the decorative arts. This, luckily, was also happening in Spain and according to the anonymous author it was 'useless to flee what necessity, logic and tradition had accomplished over the centuries' (Revista de Oro 1926).

Not only were houses and their interior decoration nationalised during this period, but also gardens. Anne Helmreich has shown how in England towards the end of the nineteenth century gardening became associated with national identity. Various authors quarrelled over the establishment of a national canon of garden styles from the past (2002). The trend to nationalise gardens was not limited to Great Britain. In Spain, the young pedagogue José Mallart for instance criticised the widespread fashion among better-off Spaniards to imitate English gardens with lawns and beds of flowers, which in the arid and sober Castilian plains were doomed to failure. The restored House of El Greco on the other hand had a beautiful garden that was in tune with the climate, the vegetation and the natural surroundings of the city of Toledo. By carrying on the local traditions both the house and the garden looked as if they 'naturally sprang out of the Castilian soil' (Mallart 1926: 495-6). A few years later in Nazi Germany Alwin Seifert designed the gardens of a model village in a simple style to give them a rural feel and let them fit in with the environment and traditions of the Lower Rhine area around Düsseldorf. However, he also explicitly used only 'native' plants and trees (Schäfers 2001: 295-98). Garden activists thus not only stimulated the use of vernacular traditions and native plants, but often also actively excluded outside influences and 'alien' species.

That the nationalisation of the domestic space of so many new dwellings was not a sudden and widespread craze, which primarily affected the upper classes who could afford a new suburban villa, but part of a wider nationalist programme, became particularly evident in the newly created garden cities, which was another English invention of the late nineteenth century. Garden cities were intended to solve the overcrowding of the rapidly growing cities and were based on the utopian and extremely rational ideas of Ebenezer Howard. However, the architects of the first garden cities of Letchworth and Hampstead, Raymond Unwin and Barry Parker, completely transformed Howard's initial symmetrical lay-out. By using winding streets, irregular squares, cul-de-sacs and neo-vernacular cottages, they hoped to create an organic community where the well-to-do and the working classes would live 
together in harmony (Meacham 1999). From about 1905 this recipe was repeated all over the continent, although in practice many garden-cities were picturesque suburbs (Ward 1992; Girard and Fayolle Lusac 1996).

Garden cities were expressly meant to uplift the lower classes by influencing their behaviour and converting them into good and loyal citizens of the nation. This was done by providing all houses with a bathroom in order to improve personal hygiene, with separate bedrooms for boys and girls, with a cosy living room or large kitchen where the family could gather and with a garden where both children and parents could relax. A healthy family life in a pleasant environment would stimulate the development of the young and prevent the adults from seeking entertainment in bars. Further, by integrating the dwellings into the surrounding nature and wrapping them in a vernacular style inspired by local artisanal traditions, it was hoped that the inhabitants would feel more connected to their surroundings. Neo-vernacular architecture thus clearly had a role in the nation-building process and in this case particularly targeted the working classes (Storm 2010: 101-11, 140-7, 178-83). The critic Erich Haenel, for instance, remarked about the early German garden city of Hellerau, near Dresden, that such suburbs would be a 'weapon in the struggle for social peace' (Haenel 1911: 343). His Spanish colleague, Hilarión González Castillo, even affirmed that garden cities could help solve the 'great social plagues of emigration, alcoholism, criminality, lack of civilisation, prostitution, tuberculosis, social conflict and misery' (Castillo 1914: 43-4). ${ }^{4}$

Fashions come and go, however, and neo-vernacular architecture was no exception, although this would only become clear in the decades after the First World War. In most belligerent countries plans were made to reconstruct the devastated areas in a neo-vernacular style (Vigato 1994: 75-118; Frank 1992). However, considering the magnitude of the destruction, the depth of the post-war economic crisis and the severity of the housing shortage, policies were rapidly revised after the war in order to build as efficiently as possible. As a consequence, most of the rebuilding was done in a rational way, using a sober and uniform construction style, while prefabricated concrete elements were now widely used instead of the artisanal traditions that had been propagated during the war (Vigato 1994: 11828; Clout 2005). On top of that, during the 1920s and 30s, the modern functionalist architecture propagated by Walter Gropius, Ludwig Mies van der Rohe and Le Corbusier became the latest trend and after 1945 their followers definitively erased neo-vernacular tendencies from the artistic map. ${ }^{5}$ Neo-vernacular architecture only survived in tourist areas, where it was useful as traditional houses, hotels and restaurants functioned as highly recognisable markers of regional 'authenticity'.

Over time these new neo-vernacular styles were accepted as logically attached to a certain territory. In the beginning the new style certainly was not taken for granted. Before the First World War it was generally presented by its propagators as new and modern and was perceived as such. Thus the invented character of the new building tradition was still obvious. This, for example, became evident when well-to-do farmers in Mecklenburg rejected the proposal of a local architect to construct a picturesque house for them by using local building traditions. They preferred cosmopolitan, symmetrical houses as they had seen in the big cities (Schur 1907: 353). In a similar way, during post-war reconstruction inhabitants of East Prussia preferred cheerful South-German houses instead of dwellings that were inspired by the more austere local vernacular traditions (Stahl 1919-20). Thus, people did not yet identify with buildings that presumably were part of their own collective heritage and even found it strange to apply this to newly built, modern houses. Neo-vernacular dwellings thus were not a logical choice and anything but banal.

Nonetheless, with the passing of years and the spread of the new regionalised or nationalised domestic spaces they became more widely accepted and just another stylistic option. During the 1920s and 30s, French architects often offered their clients a choice: a villa 
with a determined surface and lay-out could be either constructed in a neo-vernacular or a modern style. Sometimes various regional models such as Breton, Basque or Normand were available. Moreover, it became quite normal to adopt models from elsewhere. Thus in La Baule, in the south of Brittany, one could find villas in a Breton, Basque, Flemish and Provencal style (Toulier, 2001: 101-2). And as the international diffusion of the Swiss chalet and the English cottage can testify, one could also opt for foreign types, thus further banalising the quite obvious nationalistic intentions of the early propagandists of neovernacular architecture, but at the same time confirming and taking for granted the existence of various national building styles.

\section{Nationalising Domestic Practices}

At the same time that houses, furniture and gardens became explicitly attached to the nation, the same also happened with domestic practices such as cooking, cleaning and consuming. The best studied of these practices is without a doubt cooking and recently the impact of nationalism on the cuisine has received some scholarly attention. However, when dealing with nationalist influences, most food historians are not very much aware of the latest developments in nationalism studies, while those experts on nationalism that deal with this topic mostly concentrate on very recent developments (Ichijo and Ranta 2015).

From these recent studies a broad outline of this process can be obtained, in which the traditional focus in food studies on social differences becomes evident. Thus in a fascinating overview, food historian Rachel Lauden argues that around 1650 French haute cuisine - or more precisely the cuisine of the French king and nobility - became the pan-European high cuisine. Only in the Dutch Republic and England the bourgeoisie and the gentry developed their own 'middling cuisines' with more modest, home-cooked food, while the poor all over the continent just ate what they could afford. Dutch and English cooking habits and dishes were exported to settlers in the colonies and middle-class groups elsewhere in Europe. Over time, some dishes, such as roast beef, became identified as attached to English identity. However, this national identification was as much directed to the aristocratic upper-classes who preferred refined French dishes as to the French, most of whom could not afford haute cuisine (Laudan 2013: 207-235; see also Rogers 2003).

Other authors have made clear that in the more peripheral parts of the Western world, well-educated people often had a notion that their own cuisine differed from the international standards. In exceptional circumstances this opposition could even be defined in national terms. Thus Americans were aware that corn was not part of the European diet and during the American War of Independence these differences were magnified in order to distinguish themselves from the English (Vester 2015). Russians knew that cabbage soup and rye bread were not eaten in the 'civilised world'. Moreover, the consciousness of having their own rather vaguely defined cuisine was heightened by the fact that Western recipes for lent were not suitable for Orthodox Russians who also had to abstain from eating fish, eggs and dairy products (Smith 2008). Spaniards, in turn, were familiar with the regular complaints of foreign travellers about the abundant use of garlic, chick pies and fried dishes (Núñez Florencio 2004). Thus, some awareness of geographical differences in culinary traditions certainly existed, but these were only rarely expressed in national or nationalistic terms.

The main exception would be France. During the Ancien Régime haute cuisine was primarily associated with the court in Versailles, which set the tone for the other royal houses and the aristocracy. This began to change with the French Revolution and haute cuisine slowly became associated with the French nation (Laudan 2013: 222-26). During the nineteenth century famous chefs such as Marie-Antoine Carême and Auguste Escoffier increasingly profiled refined cooking as essentially French (Ferguson (2004: 49-83). In this 
manner haute cuisine followed the path of the other fine arts, such as painting, architecture and music which were also redefined along national lines, but with the exception that in cooking this primarily happened in France. As cookbooks and restaurant menus can testify, the French cuisine continued to dominate the gastronomic landscape all over the Western world.

Laudan argues that only towards the end of the nineteenth century, rising standards of living and the standardisation of food production enabled wider groups in the population to get access to the existing middling cuisines. White bread, meat and a higher intake of fats and sugar even became available to large parts of the wage-earning working classes. Meanwhile, cookbooks, magazines and cooking schools implicitly created their own national imagined communities, while the number of cheap restaurants that served simple dishes grew rapidly. As a consequence, 'the new middling cuisines became identified as national cuisines, making the world's culinary geography in 1920 radically different from that in 1840' (Laudan 2013: 248-306, quote 249). But how and why these cuisines exactly became identified as national does not become very clear.

If we take a closer look, however, it becomes evident that like in domestic architecture, nationalist activists took the lead in consciously constructing and propagating a new national cuisine. Exceptionally outspoken was the well-known Spanish novelist Emilia Pardo Bazán, who openly pleaded for the nationalisation of all domestic practices. In a speech at the recently opened Domestic Science School in Madrid she argued that the First World War, which was still going on at that moment, had shown that the idea of the fatherland was an immense reality, 'something natural like the circulation of blood'. As a consequence, women also had a great responsibility in stimulating the well-being of the nation. The fatherland should be omnipresent at home; healthy soldiers could only be born and raised by strong and disciplined mothers. In order to avoid the 'decadence of the race' she even pleaded for physical education for women (Pardo Bazán 1919: 86 and 95-6).

However, she not only advocated a nationalist role of women in giving birth and educating children; they should also adapt themselves to the national environment in their domestic duties and it was not enough to merely dismiss foreign customs that were not compatible with the Spanish national character. Pardo Bazán urged her listeners to thoroughly hispanicise their homes, beginning with the cuisine. According to her, it was necessary to return to using:

...food that sustained the living of our ancestors and that continues to sustain our farmers, fishers and shepherds and which was enforced upon us by our resources and our local and regional needs and which puts ourselves into contact with the basic elements of our nationality.

Not only should housewives cook Spanish dishes, they should also adapt themselves to national customs in their other housekeeping activities. Thus, according to the novelist, people of every nation or region had to combine modern hygienic measures with the traditional way of cleaning, which was different in every area and which was 'always the best'. Also in the decoration of the house, the patio or the garden, national traditions should be privileged (Pardo Bazán 1919: 98-100).

That this was not an exaggerated response of a Spanish author to the wholesale mobilisation of the home front that was going on at the same time in France, Germany and other belligerent countries, is shown by a fascinating study by Nancy Reagin on the nationalisation of housekeeping in Germany. In the decades around the turn of the century associations of housewives and women's magazines propagated 'proper' ways of housekeeping, like Pardo Bazán did in Spain. German housewives, whether they were 
Protestant, Catholic or Jewish, were supposed to embrace 'similar domestic standards for cleanliness, order, and thrift', which were routinely defined as 'German' (Reagin 2007: 34). Through magazines and housekeeping courses these national habits, such as having 'snow white' linens and curtains and putting up fruits and vegetables for the winter, were actively propagated, not only among middle-class women in the cities, but also among housewives in the German colonies, those from a rural background or women from the lower classes (Reagin 2007: 16-72; See for the Irish case MacPherson 2012). During the Second World War the Nazis even imposed them on the Volksdeutsche who were transferred to their new homes in the conquered areas of the East. These women and their female tutors thus had an active role in creating a 'living wall of ethnic Germans in occupied Poland' (Reagin 2007: 217).

Nonetheless, the most important practice that was nationalised was cooking, because more than cleaning this could be seen as an 'authentic' expression of the 'national spirit'. Towards the end of the nineteenth century a reaction against the French culinary dominance set in. In Spain, this began quite modestly in the 1870s when two authors began to complain that the menus at official receptions of the Spanish king were composed in badly written French and did not contain Spanish fare. They deplored that there was no real national dish like the pot-au-feu in France, roast-beef in England or risotto in Italy. In order to create the 'gastronomic unity' of the country an inventory of the best recipes of the different parts of the country was badly needed (Thebussem 1888: 178-80 and 200-1). In the German Empire, at about the same time the German Language Association published a small culinary dictionary in order to promote the use of German when drawing up a menu. As a result, in 1888 Kaiser Wilhelm II decreed that as far as possible imperial menus had to be written in German (Heinzelmann 2014: 209).

In Spain it would take some time before an inventory of the country's best recipes was made. Finally, it would be Emilia Pardo Bazán who in 1913 published La cocina antigua española and which contained a compilation of old Spanish recipes classified according to the type of dish, starting with soups and finishing with deserts. Because she did not provide indications for the geographical origin of the recipes, one can argue that although Pardo Bazán maintained that she merely uncovered what already existed, she in fact constructed or 'invented' Spanish cuisine. In the prologue she explained that a nation's cuisine is an ethnographic document, which expresses its popular spirit. The intimate connection between food, soil and popular customs gave Spanish cooking its unique character: 'The Spanish cuisine could be praised for its strong and clear flavours and lacks ambiguous sauces and seasonings'. It had adapted itself perfectly to the products of the Spanish soil and the customs of the inhabitants and therefore 'the foundation of our table should be, by natural law, Spanish' (Pardo Bazán 1913a: III-VI; see also Storm forthcoming).

Elsewhere a reaction to French culinary hegemony also set in and culinary authors began to define their own national cuisine, while primarily targeting housewives instead of male chefs (see Helstosky 2004; Parasecoli 2014; Scholliers and Greyzen 2010). Even in France a growing interest in vernacular traditions resulted in the discovery (or construction) of a rich variety in regional cuisines. In 1921, Curnonsky, the best known gastronomic author of the period, began to publish a series of over twenty volumes entitled La France Gastronomique: Guides des merveilles culinaires et des bonnes auberges françaises (Csergo 1996). In Italy this example was followed in 1931 by the Italian Touring Club, which published a Guida gastronomica d'Italia to highlight the various regional specialities of the country (Parasecoli 2014: 177-178; see for the American South: Cooley 2015). The Spanish National Board of Tourism commissioned Dionisio Pérez to write a Guía del buen comer español, in which he described the best and most characteristic dishes of the country's regions. In this culinary guide he maintained that during the eighteenth and nineteenth century the nation's taste had been frenchified, but that fortunately in more recent times Spanish 
cuisine had been revived. Like the neo-vernacular architects he argued that Spanish national cuisine consisted of a harmonious unity of different regional cuisines, which each reflected its natural conditions and local traditions (Pérez 1929). At about the same time, the first guides of regional cuisines, such as those of the Basque Country and Catalonia, were published. Within a few decades references to Spanish cuisine had become ubiquitous and quickly most cookbooks were dedicated to Spanish national or a specific regional cuisine (Martínez Llopis1993).

Shortly afterwards, when the first effects of the Wall Street Crash of 1929 began to be felt in Spain, Pérez published another book - commissioned by the National Union of Agricultural Exports - with seventy recipes to promote the domestic consumption of oranges. Later on he would propose the introduction of a national rice day, also meant to stimulate the Spanish economy (Anderson 2013: 139-44). These attempts to propagate the consumption of specific national products were anything but banal and the same was true for protectionist pleas in Germany to stimulate the consumption of 'patriotic grain' by eating rye bread, or the habit of presenting the preparation of quark, which was made from milk left over from butter production, as a patriotic duty for housewives (Reagin 2007: 95-8). Over time quark, dark bread and oranges came to be seen as typical national products.

In the meantime, commercial companies had already started to market their products, often in a more subtle way, by linking them to a specific national identity. This was particularly true for foodstuffs that could be connected to the soil and to - at least in theory an artisanal production process. Producers of cheese, wine, brandy and other beverages began to organise themselves in order to protect their wares and to guarantee certain minimum quality standards. As a consequence, they presented their products as intimately connected with the soil, climate and traditions of a particular territory, such as Champagne, Bourgogne, Cognac or Roquefort (Guy 2003; Vabre 2015). In 1919, this was institutionalised when the French government created the appellation d'origine contrôlée, which applied to wines, but in 1925 was extended to cheese as well. Other countries rapidly followed and in Spain Rioja wine became a protected trademark in 1925 (Pan Montojo 1994: 286-290).

As with architecture and furniture, the marketing of products linked to a specific territory and the custom of defining cuisines by nation, which could be subdivided further into a rapidly growing amount of regional dishes and local specialties, was quickly taken for granted. The nation thus invaded the domestic sphere and housewives could fulfil their patriotic duty by cooking, cleaning and decorating their homes according to national traditions. While in the beginning many of these duties were seen in a nationalist light, preparing a Spanish tortilla, a German Bratwurst or an Italian risotto rapidly became routine. In the beginning the new national cuisines were largely limited to the middle and upper classes; they were the ones who regularly used cookbooks, ate at restaurants that offered 'home cooked' meals and tasted regional specialties during holidays or short excursions. As more people gained access to these national middling cuisines, it became increasingly normal, also for wider strata of the population, to connect dishes to specific territories. Moreover, unlike with neo-vernacular architecture that largely disappeared after 1945, this proved not to be a passing fashion and continues until the present.

Authors such as Pilcher (1998) and Cwiertka (2006) have made clear that the conscious definition of a national cuisine also took place outside of Europe. Moreover, the timing, both in the case of Mexico and Japan, was very similar. However, the opposition between indigenous traditions and Western practices was larger and quite some culinary engineering was needed to create a new national cuisine that was recognised at the international stage as well.

\section{Conclusion}


Although further research is needed to further corroborate and refine these results, we can already draw some conclusions. It is clear that in the case of domestic architecture and decorative arts the nationalisation of the domestic sphere was a concerted action taken by reform-minded architects, designers and critics with a clear nationalist agenda in mind. Instead of housing people in rootless dwellings, arbitrarily clad in historicist styles from various periods and areas, they preferred to construct houses inspired by artisanal traditions, while using locally available materials and vernacular forms. The result of these efforts was intended to reinforce the sense of place and strengthen the bond of the inhabitants with their region and nation.

A similar process happened with domestic practices such as cooking. Again it was a small group of activists who propagated the nationalisation of the cuisine by making an inventory of the 'typical' dishes of the various parts of the fatherland. Thus, a wide array of cooking practices became part of a national culinary heritage that was further defined and disseminated by cook books, women's magazines and domestic science courses. Initially nationalist motives were clearly present, but over time, people seemed to have become accustomed to defining dishes by their geographical provenance, while considering the existence of different national cuisines as an obvious fact.

At the beginning both processes had more impact among the urban upper and middle classes. They were the ones that could afford a second home or a villa in the new regionalist style, they went to restaurants that advertised regional dishes and home-cooking and they formed the public that was targeted by authors of cookbooks and recipes in illustrated magazines. However, these innovations also rapidly began to affect rural areas and the lower classes, for instance with the construction of neo-vernacular garden cities, by way of the popular press or during domestic science courses. Over time, both trends became accepted and even taken for granted.

There was one great difference: since architecture was part of high culture, neovernacular architecture did not become omnipresent. It constantly had to compete with newer trends. Functionalism in particular - also known as the International Style - radically opposed the neo-vernacular trend, depicting it as backward, sterile and parochial. This did not happen with cooking (probably with the exception of haute cuisine), which remained part of lower or popular culture. Therefore it was not a problem that it remained stagnant (or timeless). Tradition, experience (specifically of grandmothers), the connection with the soil or terroir and its natural products were seen as positive qualities. Thus the natural division of cuisines along national borders, each with a rich regional and local variety, is seen as something completely obvious.

This divergence can also partly be explained through gender differences. ${ }^{6}$ Haute cuisine and architecture were the domain of male professionals and thus had to innovate and incorporate the newest cultural trends. Cooking, on the other hand, was one of the main tasks of (middle class) housewives and as guardians of national and regional traditions they were supposed to integrally pass on the culinary patrimony of the nation.

In the end, it has become clear that the nationalisation of the domestic sphere that began during the Fin-de-Siècle was caused by the rise of a new cultural trend and was primarily driven by a small elite, which by pleading for the nationalisation of everyday life had a profound impact upon domestic architecture, the decorative arts, gardening, cooking, cleaning and consumption. All the tendencies I have discussed occurred more or less simultaneously and the motives of the propagators in the beginning were similar and obvious. One could therefore argue that the nationalisation of the domestic sphere constituted a new phase in the nation-building process, which now also began to affect quotidian practices and objects in the private realm. Over time the nationalist content of many of these innovations 
was largely forgotten and the association of cuisines, dishes, building types and furniture with specific nations is now entirely taken for granted.

Finally, overlooking the profound impact of nationalism on both high and low culture, one wonders to what extent national cultures really were 'unique', 'original' and 'authentic'. Were they not, in fact, the product of deliberate attempts by dedicated nationalist to pressure existing social or local practices and traditions into rather generic national moulds, which rapidly became new global standards?

\section{References:}

Anderson, L. 2013. Cooking up the Nation: Spanish culinary texts and culinary nationalization in the late nineteenth and early twentieth century. Woodbridge: Tamesis.

Applegate, C. 1990. A Nation of Provincials: The German Idea of Heimat. Berkeley: University of California Press.

Baycroft, T. and M. Hewitson (eds.) 2006. What is a Nation? Europe 1789-1914. Oxford: Oxford University Press.

Bell, D.A. 2003. The Cult of the Nation in France: Inventing Nationalism, 1680-1800. Cambridge, Harvard University Press.

Bergdoll, B. 2000. European Architecture, 1750-1890. Oxford: Oxford University Press.

Berger, S. with C. Conrad 2015. The Past as History: National Identity and Historical Consciousness in Modern Europe. Basingstoke: Palgrave.

Bertho-Lavenir, C. 2001. 'L'Idée régionaliste: naissance et développement' in: F. Loyer and B. Toulier (eds.), Le Régionalisme, architecture et identité. Paris: Editions du Patrimoine: 28-48.

Billig, M. 1995. Banal Nationalism. Londres: Sage.

Blom, I., Hagemann, K. and Hall C. (eds.) 2000. Gendered Nations: Nationalisms and Gender Order in the Long Nineteenth Century. London: Bloomsbury.

Broers, M. 2015. 'The First Napoleonic Empire, 1799-1815' in: S. Berger and A. Miller (eds.), Nationalizing Empires. Budapest: Central European University Press.

Cabo, M. and F. Molina 2009. 'The Long and Winding Road of Nationalization: Eugen Weber's Peasants into Frenchmen in Modern European History (1976-2006)', European History Quarterly 39-2: 264-286.

Campbell, J. 1978. The German Werkbund: The Politics of Reform in the Applied Arts. Princeton: Princeton University Press.

Castillo, H.G. del 1914., 'Ciudades jardines y ciudades lineales (conclusión)', La Construcción Moderna, 43-4.

Clout, H. 2005, 'The Great Reconstruction of Towns and Cities in France 1918-1935', Planning Perspectives, 1-34.

Cócola Gant, A. 2013. 'The Invention of the Barcelona Gothic Quarter', Journal of Heritage Tourism 9, 1: 18-34.

Cooley, A.J. 2015. To Live and Dine in Dixie: The Evolution of Urban Food Culture in the Jim Crow South. Athens: University of Georgia Press.

Croisilles, M. 1909. 'Vers l'art social', L'Architecture Moderne 1-1: 3-5,

Crowley, D. 2001. 'Finding Poland in the Margins: The Case of the Zakopane Style', Journal of Design History 14, 2: 105-116.

Csergo, J. 1996. 'L'émergence des cuisines regionales' in: J.-L. Flandrin, M. Montanari (eds.), Histoire de l'alimentation. Paris: Fayard: 823-41. 
Cwiertka, K.J. 2006. Modern Japanese Cuisine: Food, Power and National Identity. London. Reaktion.

Díaz-Andreu, M. 2007. A World History of Nineteenth-Century Archaeology: Nationalism, Colonialism and the Past. Oxford: Oxford University Press.

Edensor, T. 2002. National Identity, Popular Culture and Everyday Life. Oxford: Berg.

El Mundo en Auto. 1925. 'Cocinas rurales', July-August 1925: 193-6.

Ferguson, P. P. 2006. Accounting for Taste: The Triumph of French Cuisine. Chicago: Chicago University Press.

Forthuny, P. 1913. 'À la recherché des beaux métiers régionaux', L'Architecture Moderne, June-July $1913: 221-2$.

Frank, H. 1992. 'Heimatschutz und typologisches Entwerfen: Modernisierung und Tradition beim Wiederaufbau von Ostpreussen 1915-1927' in V.M. Lampugnani, V.M. and R. Schneider (eds.), Moderne Architektur in Deutschland 1900 bis 1950: Reform und Tradition. Stuttgart: Hatje Cantz: 105-33.

Girard, P. and B. Fayolle Lusac (eds.) 1996. Cités, cites-jardins: Une histoire européenne. Toulouse: MSHA.

Guy, K. M. 2003. When Champagne Became French: Wine and the Making of a National Identity. Baltimore: Johns Hopkins University Press.

Haenel, E. 1911. 'Die Gartenstadt Hellerau', Dekorative Kunst, April 1911: 297-343.

Hagen, Y. 2006. Preservation, Tourism and Nationalism: The Jewel of the German Past. Aldershot: Ashgate.

Harp, S. L. 2001. Marketing Michelin: Advertising and cultural identity in twentieth-century France. Baltimore: Johns Hopkins University Press.

Heinzelmann, U. 2014. Beyond Bratwurst: A history of food in Germany. London: Reaktion.

Helmreich, A. 2002. The English Garden and National Identity: The Competing Styles of Garden Design, 1870-1914. Cambridge: Cambridge University Press.

Helstosky, C. F. 2003. Garlic and Oil: Politics and Food in Italy. Oxford and New York: Bloomsbury.

Heuss, T. 1910. 'Landhaus Adolfshütte', Dekorative Kunst, May 1910: 347-57.

Hutchinson, J. 2006. 'Hot and Banal Nationalism: The Nationalization of "the Masses"' in G. Delanty and K. Kumar (eds.), The Sage Handbook of Nations and Nationalism. London: Sage: 295-306.

Ichijo, A. and Ranta R. 2016. Food, National Identity and Nationalism: From Everyday to Global Politics. Basinstoke: Palgrave Macmillan.

Jones, R. and P. Merriman 2009. 'Hot, Banal and Everyday Nationalism: Bilingual Road Signs in Wales', Political Geography, 28: 164-73.

King, J. 2002. Budweisers into Czechs and Germans: A Local History of Bohemian Politics, 1848-1948. Princeton: Princeton University Press.

Lampugnani, V.M. and R. Schneider (eds.) 1992. Moderne Architektur in Deutschland 1900 bis 1950: Reform und Tradition. Stuttgart: Hatje Cantz.

Landan, R. 2013. Cuisine and Empire: Cooking in World History. Berkeley: University of California Press.

Lane, B.M. 2000. National Romanticism and Modern Architecture in Germany and the Scandinavian Countries. Cambridge: Cambridge University Press.

Laserre, C. 1986. 'Le Néo-basque : une autre face de la modernité (1920-1940)', Monuments Historiques, October-November: 65-73.

Leerssen, J. and A. Rigney (eds.) 2014. Commemorating Writers in Nineteenth-Century Europe: Nation-Building and Centenary Fever. Basingstoke: Palgrave Macmillan.

Leerssen, J. (ed.) 2016. Encyclopedia of Romantic Nationalism in Europe. Amsterdam University Press. 
Loyer F. and B. Toulier (eds.) 2001. Le Régionalisme, architecture et identité. Paris: Editions du Patrimoine.

Maciuika, J.V. 2005. Before the Bauhaus: Architecture, Politics and the German State, 18901920/ Cambridge: Cambridge University Press.

MacPherson, D.A.J. 2012. Women and the Irish Nation: Gender, Culture and Irish Identity, 1890-1914. Basingstoke, Palgrave Macmillan.

Martínez Llopis, M. 1993. 'Prólogo' in: T. Bardají, Índice culinario Huesca, La Val de Onsera: $13-22$.

Maumené, A. 1913. 'Sweet Home, villa du littoral normand: À Mme Fernand Renault, Cabourg (Calvados)', La Vie à la Campagne, 1 January 1913, 11-17.

Meacham, S. 1999. Regaining Paradise: Englishness and the Early Garden City Movement. New Haven: Yale University Press.

Menéndez Robles, M.L. 2007. El Marqués de la Vega Inclán y los orígenes del turismo en España. Madrid: Ministerio de Industria, Turismo y Comercio.

Muthesius, H. 1908 [1904], Das englische Haus. Entwicklung, Bedingungen, Anlage, Aufbau, Einrichtung und Innenraum. Berlin: Wasmuth.

Navascués Palacio, P. 1985. 'Regionalismo y arquitectura en España (1900-1930), Arquitectura \& Vivienda 3: 28-36.

Núñez, X.-M. 2001. 'The Region as Essence of the Fatherland: Regionalist Variants of Spanish Nationalism (1840-1936)', European History Quarterly, 31-4: 483-518.

Núñez Florencio, R. 2004. Con la salsa de su hambre. Los extranjeros ante la mesa hispana. Madrid: Alianza.

Ogata, A.F. 2001. Art Nouveau and the Social Vision of Modern Living: Belgian Artists in a European Context. Cambridge: Cambridge University Press.

Pan Montojo, J. 1994. La vid y el vino en España, 1800-1936. Madrid: Alianza.

Parasecoli, F. 2014. Al dente: A history of food in Italy. London: Reaktion.

Pardo Bazán. E. 1913a. La cocina española antigua. Madrid: Renacimiento.

Pardo Bazán, E. 1913b. La cocina española moderna. Madrid: Renacimiento.

Pardo Bazán. E. 1916. 'Conferencia de la Excma. Sra. Condesa Pardo Bazán (día 3 de diciembre de 1916)' in: Conferencias dadas en la Escuela del Hogar y Profesional de la Mujer. Curso de 1916 a 1917. Madrid: Cleto Vallinas: 85-102.

Pérez, D. 1929. Guía del buen comer español. Inventario y loa de la cocina clásica de España y sus regiones. Madrid: Velázquez.

Pilcher, J.M. 1998. ;Que vivan los tamales! Food and the Making of Mexican Identity. Albuquerque: University of New Mexico Press.

Popp, J. 1913. 'Haus Schwalten von Richard Riemerschmid', Dekorative Kunst, October 1913: 1-11.

Quiroga, A. 2013. Football and National Identities in Spain: The Strange Death of Don Quixote. Basingstoke: Palgrave Macmillan.

Reagin, N.R. 2007. Sweeping the German Nation: Domesticity and National Identity in Germany, 1870-1945. Cambridge: Cambridge University Press.

Revista de Oro. 1926. 'El arte moderno y los estilos', April 1926: 238-240.

Rogers, B. 2003. Beef and Liberty: Roast Beef, John Bull and the English Nation. London: Chatto \& Windus.

Schäfers, S. 2001. Vom Werkbund zum Vierjahresplan. Die Ausstellung ,Schaffendes Volk', Düsseldorf 1937. Düsseldorf: Droste.

Scholliers, P and A. Greyzen 2010. 'Upgrading the Local: Belgian Cuisine in Global Waves', Gastronomica. The Journal of Food and Culture, 10-2: 49-54.

Schur, E. 1907. 'Rittergut Wendorf und Haus Korff', Dekorative Kunst, June 1907: 353-69.

Seesselberg, F. 1910. 'Niedersachsenkunst', Der Baumeister, May 1910: 86-96. 
Sézille, L. 1908. 'Reconstitution d'une gentilhommière normande', La Vie à la Campagne, 15 June 1908: 343-4.

Sézille, L. 1909. 'Une maison en Pays Basque', La Vie à la Campagne, 1 Septembre 1909: 153-4.

Silver, K.E. 1989. Esprit de Corps: The Art of the Parisian Avant-Garde and the First World War, 1914-1925. Princeton: Princeton University Press.

Skey, M. 2009. 'The National in Everyday Life: A Critical Engagement with Michael Billig's thesis of Banal Nationalism', The Sociological Review, 57, 2: 331-46.

Smith, A.K. 2008. Recipes for Russia: Food and Nationhood under the Tsars. DeKalb: Northern Illinois University Press.

Stahl, F. 1919-20. 'Hans Philipp - Hermann Dernburg', Wasmuths Monatshefte für Baukunst: 319-20.

Stauter-Halsted, K. 2001. The Nation in the Village: The Genesis of Peasant National Identity in Austrian Poland 1848-1914. Ithaca: Cornell University Press.

Stieber, N. 1998. Housing Design and Society in Amsterdam: Reconfiguring Urban Order and Identity, 1900-1920. Chicago: University of Chicago Press.

Storm, E. 2010. The Culture of Regionalism: Art, Architecture and International Exhibitions in France, Germany and Spain, 1890-1939. Manchester: Manchester University Press.

Storm, E. 2012. 'The Birth of Regionalism and the Crisis of Reason: France, Germany and Spain' in J. Augusteijn and E. Storm (eds.), Region and State in Nineteenth-Century Europe: Nation-Building, Regional Identities and Separatism. Basingstoke: Palgrave: 36-57.

Storm, E. 2013. 'Una España más española. La influencia del turismo en la imagen nacional' in J. Moreno Luzón and X. M. Núñez Seixas (eds.), Ser españoles. Imaginarios nacionalistas en el siglo XX. Barcelona: RBA: 530-60.

Storm, E. forthcoming. 'La nacionalización del hogar en España', Journal of Iberian and Latin American Studies.

Thebussem, el Doctor, un cocinero de S.M. 1888, La mesa moderna. Cartas sobre el comedor y la cocina. Madrid: Fernando Fe.

Thiesse, A.-M. 1991. Écrire la France. Le Mouvement littéraire régionaliste de langue française entre la Belle Époque et la Libération. Paris : PUF.

Thiesse, A.-M. 1999. La Création des identités nationales. Europe XVIIIe-XXe siècle. Paris: Seuil.

Thiesse, A.-M. 2012. 'The Transnational Creation of National Arts and Crafts in $19^{\text {th }}$ Century Europe (Spinlecture 2012)', http://spinnet.eu/images/pdf/Thiesse2012.pdf

Tomlinson, A. and C. Young (eds.) 2006. National Identity and Global Sports Events: Culture, Politics and Spectacle in the Olympic Games and the Football World Cup. Albany: State University of New York Press.

Toulier, B. 2001. 'L'Assimilation du régionalisme dans l'architecture balnéaire' in: F. Loyer and B. Toulier (eds.), Le Régionalisme, architecture et identité. Paris: Editions du Patrimoine: 96-110.

Tournoux, M. N. 1999. Deauville, les styles normands. Itinéraires du patrimoine. Deauville: Direction régional des affaires culturelles.

Troy, N. J. 1991. Modernism and the Decorative Arts in France: Art Nouveau to Le Corbusier. New Haven: Yale University Press.

Vabre, S. 2015. 'Constructing Roquefort Cheese at Universal Exhibitions, 1851-1914' in N. Teughels and P. Scholliers (eds.), A Taste of Progress: Food at International and World Exhibitions in the Nineteenth and Twentieth Century. Farnham, Ashgate: 18396. 
Vester, K. 2015. A Taste of Power: Food and American Identities. Oakland: University of California Press.

Vigato, J.-C. 1994. L'Architecture régionaliste. France 1890-1950. Paris: Norma.

Villar Movellán, A. 1979. Arquitectura del regionalismo en Sevilla. 1900-1935. Sevilla: Diputación Provincial de Sevilla.

Vlossak, E. forthcoming. 'Gender Approaches to the History of Nationalism' in S. Berger and E. Storm (eds.), Writing the History of Nationalism. London: Bloomsbury.

Waddy, H. 2010. Oberammergau in the Nazi Era: The Fate of a Catholic Village in Hitler's Germany. Oxford: Oxford University Press.

Ward, S. 1992. The Garden City: Past, Present and Future. London: Spon.

Wörner, W. 1999. Vergnügung und Belehrung. Volkskultur auf den Weltausstellungen, 18511900. Münster: Waxmann.

Young, C.D. 2016. Music Theatre and Popular Nationalism in Spain, 1880-1930. Baton Rouge: Louisiana State University Press.

Young, P. 2012. Enacting Brittany: Tourism and Culture in Provincial France, 1871-1939. Farnham: Ashgate.

Zuelow, E.G.E. 2009. Making Ireland Irish: Tourism and National Identity since the Irish Civil War. Syracuse: Syracuse University Press.

\footnotetext{
${ }^{1}$ That these quotes were not very exceptional is shown in Storm 2010.

${ }^{2}$ Various studies have already made clear that during this period regional identities became more closely defined. Moreover, regionalism and nationalism were mostly thoroughly intertwined and the new regional identities in general helped to make the rather abstract national identities more tangible (see Applegate 1990, Thiesse 1991; Núñez Seixas 2001). Regionalist movements pleading for devolution or even independence, such as those in Catalonia, the Basque Country and Brittany, in general were not very enthusiastic about neovernacular architecture. A Breton nationalist architect even declared that he did not want to see himself as exotic and consequently preferred the internationalist style of Le Corbusier (Storm 2010: 139-40, 154-55 and 177-78).

${ }^{3}$ This revival of the decorative arts has been widely studied, but almost always in connection with the rise of modernism. Thus in Germany, the Werkbund is studied primarily as a precursor of Bauhaus, while Ogata, Silver and Troy focus on the relationship between craft reform and the French and Belgian avant-gardes.

${ }^{4}$ The rather marginal anti-Semitic German author Theodor Fritsch proposed a similar plan to build new cities in the countryside in the late 1890s. Its goals were even more outspoken as he hoped that it would 'stop the decline of the blond race' and create new 'breeding grounds for German life' (Schubert 2004: 29).

${ }^{5}$ This was done even more thoroughly in the history of architecture, which was now refashioned as a triumphal march of architectural modernism.

${ }^{6}$ Authors such as Smith (2008), Laudan (2013) and Vester (2015) have pointed to the role of cookbooks (often also written by female authors) directed at housewives in introducing a national middling cuisine.
} 